\title{
From Food Processing Leftovers to Bioplastic: A Design of Experiments Approach in a Circular Economy Perspective
}

\author{
Silvia Barbi ${ }^{1} \mathbb{D} \cdot$ Laura I. Macavei $^{2} \mathbb{D} \cdot$ Augusta Caligiani $^{3} \mathbb{D} \cdot$ Lara Maistrello $^{2,4}\left(\mathbb{D} \cdot\right.$ Monia Montorsi $^{1,5}(\mathbb{D}$
}

Received: 27 July 2020 / Accepted: 27 January 2021

(c) The Author(s), under exclusive licence to Springer Nature B.V. part of Springer Nature 2021

\begin{abstract}
Aiming at reducing the environmental impact of low density polyethylene (LDPE) when employed as mulching film, this study was focused on the partial substitution of the material with proteins extracted from Hermetia illucens, also known as black soldier fly (BSF). Insects were reared on chicken manure and food leftovers in a circular economy perspective. To evaluate the effects of processing conditions and amount of BSF proteins on the properties of the final material the Design of Experiments technique was employed. Samples were obtained by hot mixing and compression molding, and their thickness, tensile stress, tensile strain, and Young modulus were measured and analyzed. According to mathematical models, the addition of BSF proteins in the mixture results in increased homogeneity and Young modulus of the material and in reduced tensile stress and strain. Results indicated that a LDPE-BSF proteins mixture of 50-50 wt\%, processed at relative low temperature $\left(130{ }^{\circ} \mathrm{C}\right.$ ) and time $(3 \mathrm{~min})$, ensures properties closer to pure molded LDPE (thickness $=0.8 \mathrm{~mm}$, tensile stress $=6 \mathrm{MPa}$, tensile strain $=15 \%$ and Young modulus $=200 \mathrm{MPa}$ ) with lower environmental impact thanks to the high BSF proteins addition. Thereafter, BSF proteins can be employed as additive for LDPE for agricultural purposes, with processing methods feasible in an industrial perspective.
\end{abstract}

\section{Graphical Abstract}

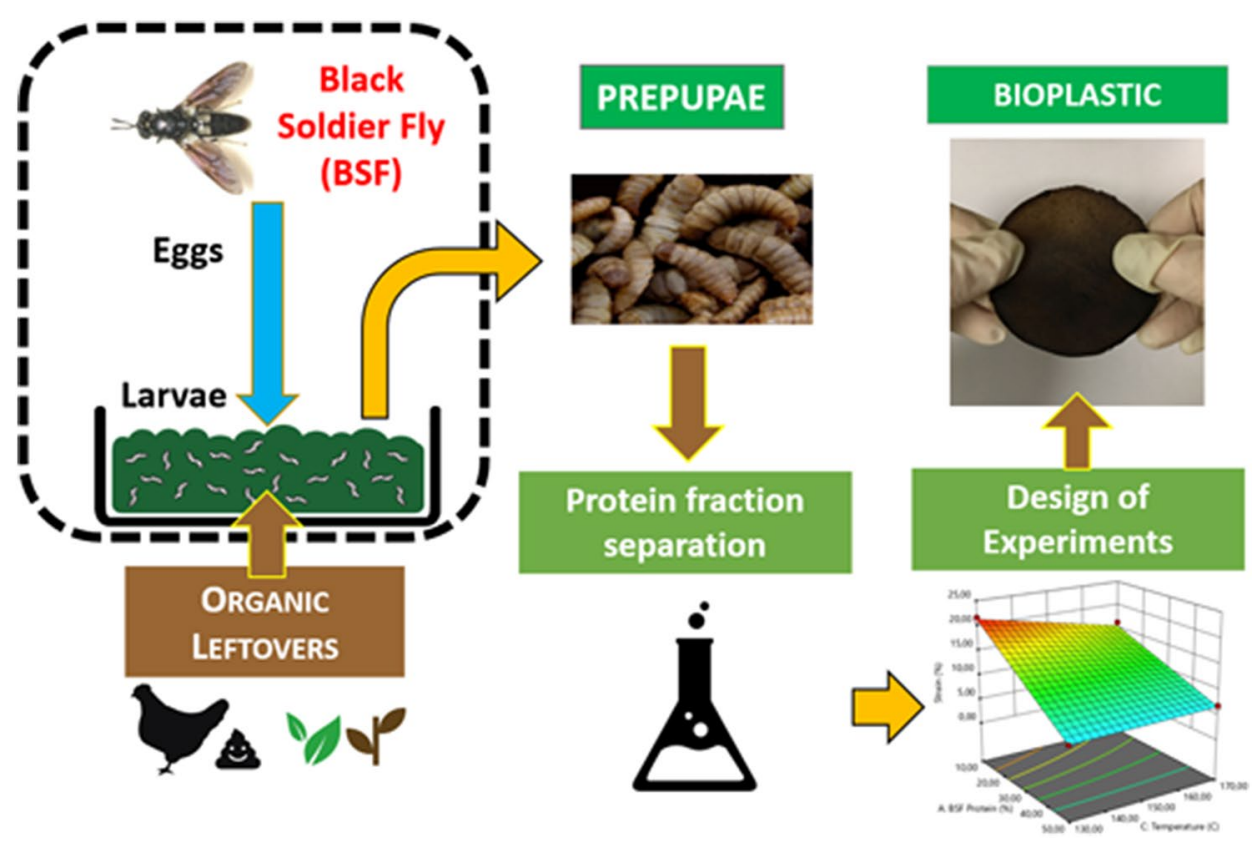

Keywords Mixture design · Agro-food leftovers $\cdot$ Insect proteins $\cdot$ Innovative biomaterials $\cdot$ Black soldier fly

Extended author information available on the last page of the article 


\section{Statement of Novelty}

In the present paper a new class of composite materials was studied to be employed in agriculture. As the request of plastic usage is arising, the availability of materials with lower environmental impact, but with similar functional properties, must follow the same trend. In this work, for the first time, proteins from insects have been tested as additive for conventional plastic, with the aim to reduce microplastic pollution. Moreover, the addition of proteins from insect open to new possibilities in a circular economy perspective due to (i) the possibility to rear insects on organic leftovers, thus considerably reducing their volume (ii) the possibility to release in the soil nitrogen and other beneficial nutrients for crops at the materials' end-life.

\section{Introduction}

Due to the increasing growth of human population and its demand for plastic materials, the research for more sustainable materials to be used for agricultural purposes is one of the main issues addressed by the European Union Council [1]. Biopolymers are thus a major research topic to overcome the strong limitation of petroleum derived plastic due to the end-life issues. The recycling process of conventional plastic in agricultural applications is expensive, time-consuming and has negative footprints for the environment, mainly because of the macro and microplastics that can remain in the soil, due to only partial degradation [2,3]. This critical issue is emphasized when mulching films are considered, due to the fact that they are remarkably close to soil and their usage is increasing continuously in recent years. Low density polyethylene (LDPE) is the petroleum derived plastic mostly employed for this specific application, and its total or partial substitution with biopolymers is currently strongly recommended $[4,5]$. Nevertheless, emerging problems of biopolymers employed for LDPE substitution, such as polylactic acid (PLA) or starch derived compounds, must be considered. A major issue is that most commercial biopolymers need a large-scale production of crop-based materials, with high consumption of soils and resources potentially available for human nutrition, in strong similarity with biofuel production $[6,7]$. Secondly, differences concerning production costs (e.g. PLA $4.75 \$ / \mathrm{kg}$ ) are not negligible when compared to PE $(1.9 \$ / \mathrm{kg})$ or PET $(1.6 \$ / \mathrm{kg})[8$, 9]. Finally, requirements of chemical additives to induce polymerization, boost plasticization and avoid fast degradation arise concerns on the environmental impact of production and recycling of LDPE—biopolymers blends [10,
11]. Therefore, biopolymer's research and development need to be geared towards minimizing agricultural land use, avoiding drawbacks when mixed with conventional plastic, and also promoting a fast and feasible industrial scale up.

In a circular economy perspective, the present study focuses on obtaining bioplastic indirectly from food waste and agricultural leftovers, thus avoiding further use of soil suitable for agricultural purposes. Therefore, at least two beneficial effects are expected, the first concerning the reduction of organic waste volume derived from food processing and the second related to a restrained employment of petroleum derived plastic. The key point of the proposed process is the employment of a scavenging insect, the black soldier fly (BSF) Hermetia illucens (Diptera: Stratiomyidae). Larvae of these insects are well-known as efficient bio-converters of a wide type of organic substrates into valuable macronutrients, such as protein and lipids, useful for several application (e.g. feed, biofuel) [12-15] and for reducing by $38 \%$ to $74 \%$ the waste's dry mass volume [16]. BSF's proteins demonstrated good perspective to constitute bioplastics film, however, data collected about degradation in the soil, showed a too fast bioconversion process [17]. In fact, as shown in a previous study, bioplastic can be obtained from BSF protein, through wet casting employing water as solvent and glycerol as plasticizer, but degradation in soil is reached in few days due to high content of biodegradable compounds [17]. In addition, for this material a high environmental impact was observed due to the energy needed for drying [15]. Thereafter, in the present study, proteins extracted from BSF's prepupae, that have been reared on food processing wastes, have been employed to partially substitute LDPE to formulate a new category of plastic, suitable as mulching film but more promising for an industrial scale-up. From this point of view, it must be noted that the increasing demand of environmentally green substitutes for LDPE is expected to enhance the request of protein as well (many kilo tons worldwide), consequently demanding an industrial scale up of BSF's rearing. Considering the above mentioned issues, the blends investigated in this study have been manufactured through hot melting and compression molding, which are suitable processes for an industrial scale-up perspective. In this context, Design of Experiments (DoE) is applied to overcome the strong limitations intrinsic into the One Factor-at-A-Time (OFAT) method, providing the maximum information content with a limited number of experiments, saving time and resources [18]. Through this methodology, statistical reliable models are expected to be generated, that describe correlations between materials formulation, processing parameters and film performances, examined downstream the experiment. 


\section{Materials and Methods}

\section{Materials}

BSF proteins employed in the present study derives from previous research, in which the insect were reared on chicken manure or food processing leftovers [13, 19]. These studies were conducted through Design of experiments technique aiming to calculate mathematical correlation among type and amount of waste with insects prepupae rearing performance and insect nutritional composition [13, 19]. In summary, BSF were obtained from composters located in Northern Italy area (provinces Modena and Cuneo) and kept under controlled conditions in climatic chambers $\left(27 \pm 0.5{ }^{\circ} \mathrm{C}, 60-70 \% \mathrm{RH}\right)$ during all period. BSF larvae were fed either with mixtures of chicken manure, water and zeolite or with mixtures of food processing leftovers until the prepupal stage was reached $[13,19]$. Subsequently, BSF proteins fraction was obtained through total protein extraction in alkali, followed by precipitation at the isoelectric point following the procedure reported in a previous study [20]. Aiming to balance the reactive surface available during the hot mixing, the protein fraction was previously dried in the oven at $65 \pm 5^{\circ} \mathrm{C}$ to remove the free water, further grounded through dry analytical mill (IKA, A10 basic) and then sieved, to ensure the homogeneity of the particle size, below $20 \mu \mathrm{m}$. LDPE technical grade (Dow chemicals) in granulate was employed as base for mixing and mulching film production. LDPE was conditioned at standard conditions $\left(25^{\circ} \mathrm{C} ; 50 \% \mathrm{RH}\right)$ for $24 \mathrm{~h}$ before mixing.

\section{Film Preparation Through Design of Experiment}

Design of experiments was employed to plan the needed tests and to analyze the results through ANOVA tool. The Design Expert 12.0 (Stat-Ease, U.S.A.) code was used. Three factors were considered for the experimental plan: amount of BSF proteins, time, and temperature of processing. These independent factors were varied according to the ranges detailed in Table 1 from which the experimental plan of Table 3 was derived. BSF proteins were employed to partially substitute LDPE, thereafter LDPE amount was modified consequently to reach $100 \mathrm{wt} \%$. Boundaries of these

Table 1 Independent factors employed for the factorial design

\begin{tabular}{lllrrl}
\hline Variable & Units & Type & Minimum & Maximum & Goal \\
\hline BSF proteins & $\%$ & Numeric & 10.00 & 50.00 & To maximize \\
Time & $\min$ & Numeric & 3.00 & 8.00 & To minimize \\
Temperature & $\mathrm{C}$ & Numeric & 130.00 & 170.00 & To minimize \\
\hline
\end{tabular}

ranges were chosen after preliminary tests, in order to reduce the number of samples with weak quality.

A full 2-level factorial design with 6 center points, for curvature identification, and 2 replicates, for pure error estimation, was chosen as experimental plan, for a total of only 22 experiments. This restrained number of tests ensures the capability of the method to generate reliable mathematical models able to investigate the scale-up of LDPE substitution with BSF proteins. To avoid environmental conditioning, the preparation and measurement of samples was performed according to the randomized run order, as shown in Table 3. LDPE - BSF hot mixing was obtained through Reomix 540 HAAK Polylab (Thermoscientific) and employing batches of $20 \mathrm{~g}$ for each sample, following time and temperature processing detailed in Table 3. Obtained blends were molded through compression (Model 4386 Bench Top Laboratory Manual Press Carver) for $3 \mathrm{~min}$ at $130{ }^{\circ} \mathrm{C}$ in order obtain films and then cooled at room temperature.

\section{Characterizations}

Homogeneity parameter evaluation was assessed as the capability to constitute a free-standing film through a consensual panel test. For this parameter, the average qualitative scores obtained were recorded as response and then analyzed by ANOVA. The panel test was carried out employing the judgements in blind of five people. The output of each experiment was evaluated considering the overall homogeneity and quality of the film. The classification number equal to the lower value corresponds to the weakest quality as well as the highest score corresponds to samples with the highest quality (e.g., film completely homogenous, with good dispersion of BSF proteins, without holes and thickness variation over the same sample). All samples were tested at room temperature. Thickness was evaluated through a digital micrometer (Mitutoyo, YY-T1BD-2GYE) in fifteen different points, and the average value was taken as reference. The sensitivity of the instrument was $0.02 \mathrm{~mm}$. A dynamic mechanical analyzer (DMA, TA Q800) was employed to collect information about tensile properties using a film tension set-up. The specimens were for first conditioned at standard conditions $\left(25^{\circ} \mathrm{C} ; 50 \% \mathrm{RH}\right)$ for $24 \mathrm{~h}$, then cut into rectangles with dimensions $20 \times 5 \mathrm{~mm}$ and then tested. After assembly and alignment in Q800 film clamps, length of each sample was measured in the film stage assembly under an applied force of $0.05 \mathrm{~N}$. The tensile properties of the films were monitored during specimen's elongation, with an applied force from 0.05 to $18 \mathrm{~N}$ at a rate of $0.05 \mathrm{~N} \mathrm{~min}^{-1}$. The data analyzed in this study refers to tensile stress at break (Stress), tensile strain at break (Strain) and Young Modulus $(E)$ calculated as the slope of the initial region of the stress strain curve from 0.05 to $0.25 \%$ of strain according to EN ISO 527-1 standard [21]. 


\section{Statistical Analysis}

Analysis of variance (ANOVA) was employed to evaluate the cability of the data to describe a reliable relationship (model) between independent factors (Table 1) and final materials properties. ANOVA works defining that a statistical difference among samples can be assessed when the variation among all the samples, usually due to independent factor changes, is larger enough than the variation within samples obtained in the same experimental conditions [18]. The model and independent factors significance were assessed analyzing the regression coefficient through the p-value approach: only $\mathrm{p}$-values lower than 0.001 were considered as statistically significant and

Table 2 Desirability function conditions

\begin{tabular}{lll}
\hline Responses & Goal & Importance \\
\hline Homogeneity & To maximize & 5 \\
Thickness & To minimize & 5 \\
Stress & To maximize & 2 \\
Strain & To maximize & 2 \\
E & In range & 3 \\
\hline
\end{tabular}

therefore included for the model formulation [18]. The fitting quality of the model and its predictive power were estimated by using the $R^{2}$ and Pred- $R^{2} . R^{2}$ is the proportion of the variance of the response that is estimable from the independent factors and Pred- $R^{2}$ is similar to $R^{2}$ but calculated through the predicted values of the response [18]. Response contour plots were used as functional tools in explaining graphically the role of the main components on the final considered properties. Finally, the overall desirability function (D) was employed to balance the different responses, taking in account as weight their effective importance, and goal with respect to the overall purpose of the work. The desirability function conditions employed in the present work have been shown in Table 2 . The highest importance was attributed to Homogeneity and Thickness of the final material considering its application as mulching film. For the same reason, mechanical properties were considered less important compared to the other parameters.
Table 3 Complete experimental plan

\begin{tabular}{|c|c|c|c|c|c|c|c|c|}
\hline \multirow[t]{3}{*}{ Run } & \multicolumn{3}{|l|}{ Factors } & \multicolumn{5}{|l|}{ Responses } \\
\hline & BSF Protein & Time & Temperature & Thickness & Strain & Stress & $\mathrm{E}$ & Homogeneity \\
\hline & $\%$ & $\min$ & $\mathrm{C}$ & $\mathrm{mm}$ & $\%$ & $\mathrm{MPa}$ & $\mathrm{MPa}$ & \\
\hline 1 & 30.00 & 5.50 & 150.00 & 0.81 & 6.13 & 3.00 & 120 & 2 \\
\hline 2 & 50.00 & 8.00 & 170.00 & 0.78 & 6.87 & 3.50 & 178 & 2 \\
\hline 3 & 50.00 & 8.00 & 170.00 & 0.76 & 6.42 & 3.53 & 179 & 3 \\
\hline 4 & 10.00 & 3.00 & 170.00 & 0.80 & 6.46 & 2.64 & 69 & 1 \\
\hline 5 & 50.00 & 3.00 & 170.00 & 0.83 & 5.39 & 3.33 & 188 & 3 \\
\hline 6 & 30.00 & 5.50 & 150.00 & 0.69 & 5.50 & 3.08 & 120 & 2 \\
\hline 7 & 10.00 & 3.00 & 170.00 & 0.70 & 7.50 & 3.82 & 67 & 1 \\
\hline 8 & 50.00 & 3.00 & 130.00 & 0.95 & 1.60 & 2.41 & 211 & 3 \\
\hline 9 & 50.00 & 8.00 & 130.00 & 0.75 & 6.16 & 3.79 & 177 & 3 \\
\hline 10 & 50.00 & 3.00 & 170.00 & 0.65 & 4.98 & 3.91 & 190 & 2 \\
\hline 11 & 30.00 & 5.50 & 150.00 & 0.73 & 5.00 & 3.00 & 123 & 2 \\
\hline 12 & 10.00 & 8.00 & 170.00 & 0.45 & 16.14 & 5.82 & 108 & 1 \\
\hline 13 & 10.00 & 3.00 & 130.00 & 0.49 & 15.70 & 5.29 & 125 & 1 \\
\hline 14 & 10.00 & 8.00 & 130.00 & 0.42 & 20.99 & 6.17 & 119 & 1 \\
\hline 15 & 30.00 & 5.50 & 150.00 & 0.69 & 7.38 & 4.45 & 121 & 2 \\
\hline 16 & 10.00 & 8.00 & 170.00 & 0.70 & 14.49 & 4.62 & 109 & 1 \\
\hline 17 & 10.00 & 3.00 & 130.00 & 0.64 & 15.30 & 4.86 & 128 & 1 \\
\hline 18 & 10.00 & 8.00 & 130.00 & 0.60 & 21.71 & 5.90 & 118 & 1 \\
\hline 19 & 50.00 & 8.00 & 130.00 & 0.62 & 6.00 & 4.53 & 175 & 2 \\
\hline 20 & 50.00 & 3.00 & 130.00 & 0.80 & 2.78 & 3.41 & 209 & 3 \\
\hline 21 & 10.00 & 5.50 & 170.00 & 0.73 & 11.56 & 4.43 & 88 & 1 \\
\hline 22 & 50.00 & 5.50 & 130.00 & 0.80 & 4.53 & 3.16 & 190 & 3 \\
\hline
\end{tabular}




\section{Results and Discussion}

All the experiments planned (Table 3) were able to generate suitable samples for further measurements, without holes or strong thickness variation into the same sample. Therefore, the overall quality of the specimens obtained was good enough to perform a detailed analysis based on objective measurement. This result suggests a favorable compatibility of LDPE and BFS to be blended together in a relative wide range of component's amounts and processing variables (time and temperature). Figure 1 shows three of the samples obtained, each one representative of one group of samples with the same amount of BSF proteins. This figure indicates that, although stable materials were obtained, clear differences can be detected related to the homogeneity of the BSF proteins (dark color) dispersion in the LDPE. Therefore, a more detailed analysis was performed, through mechanical measurement and statistical analysis, in order to calculate: (1) the effect of BSF proteins poor dispersion on the overall material's behavior (2) the optimization of the amount of BSF proteins and processing parameters, thus enhancing Homogeneity and the mechanical properties as well. In this context Homogeneity parameter measured through consensual panel test was calibrated in order to give the lowest value to sample with poor dispersion of BSF proteins into LDPE (e.g., Fig. 1c). Therefore, plastic sample with an overall good physical quality were obtained (without holes or strong thickness variation).
Based on the rough evaluation of the data shown in Table 3, an overall good agreement of collected data through replicates can be detected, as well as strong variation among samples obtained in different conditions. These results suggest that the statistical analysis can be performed considering all the collected data. For the statistical analysis no further, mathematical transformation was required to codify the hierarchy of the factors or to normalize the data.

Table 4 shows ANOVA results: the estimation of the significant independent factors, their interactions, the model equations, as well as the fitting parameters of each model. Mathematical models that correlate the factors (in single or interaction) to measured data are significant for all the responses as confirmed by $\mathrm{p}$-value $<0.0001$, indicating that the probability of the data variation due to outsider factors is not statistically reliable. At the same time, the lack of fit resulted not significant for all the responses, indicating that models are significant. Moreover, as further positive consideration, curvature is not significant and therefore the central points can be considered as additional data in the regression model, thus increasing the points of the design plan. Significant terms suggest that BSF protein is the factor with the greater influence on all the responses, both as single factor and in interaction, in particular for physical properties such as Thickness or Homogeneity. On the other side, for the mechanical properties, Time seems to play a role only in interaction with other factors. Similar considerations can be further deduced by the coefficients of each mathematical model equation. $\mathrm{R}^{2}$ and Pred- $\mathrm{R}^{2}$ (Table 4 ) confirms the good fit of the data and the good predictive power of the model,

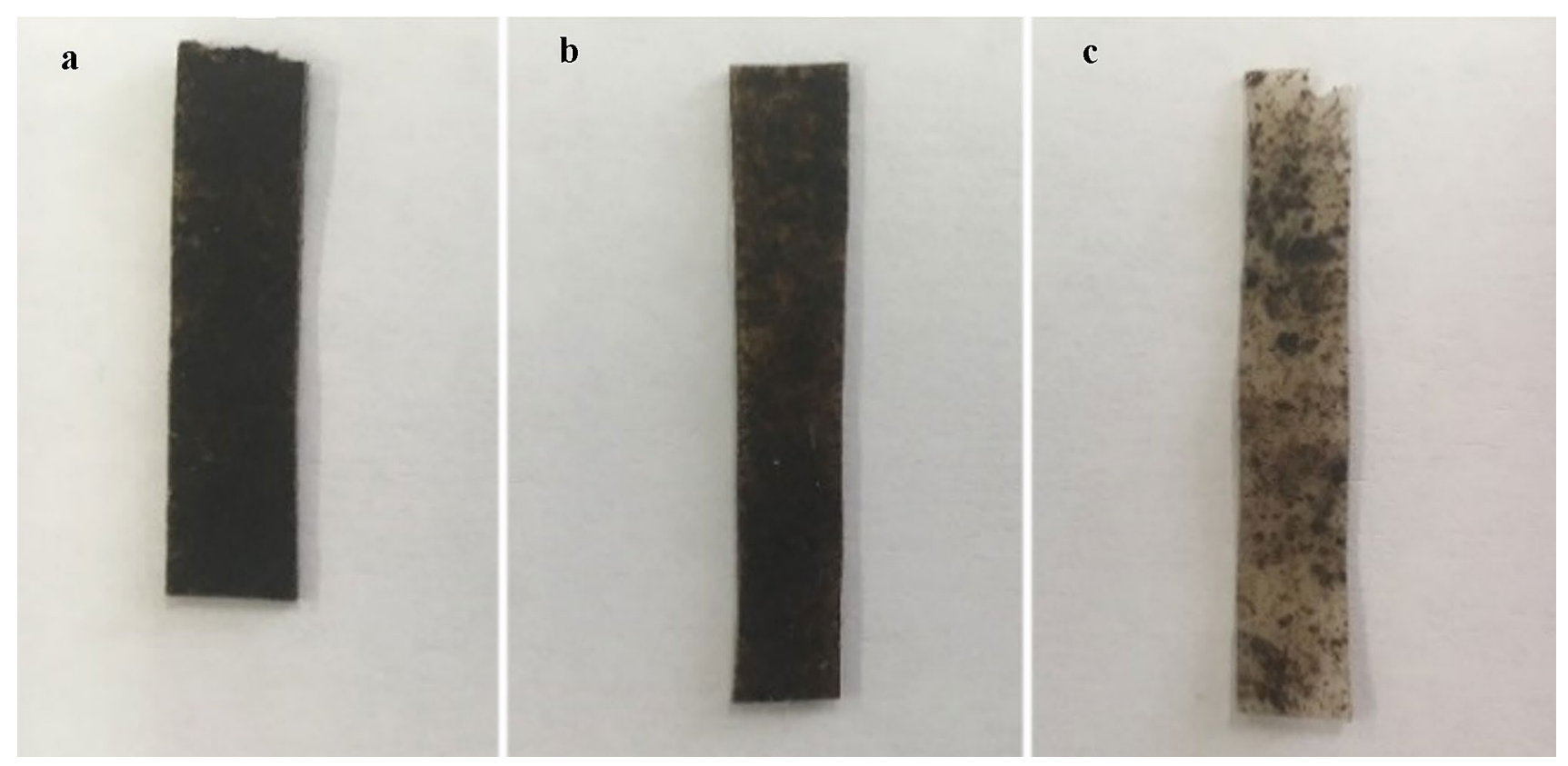

Fig. 1 Examples of the obtained samples for a BSF proteins $=50 \mathrm{wt} \%, \mathbf{b}$ BSF proteins $=30 \mathrm{wt} \%, \mathbf{c}$ BSF proteins $=10 \mathrm{wt} \%$ 
Table 4 ANOVA results

\begin{tabular}{|c|c|c|c|c|c|}
\hline Responses & p-value & Lack of fit & Significative terms & $\mathrm{R}^{2}$ & Pred- $\mathrm{R}^{2}$ \\
\hline Homogeneity & $<0.0001$ & Not significant & BSF protein & 0.86 & 0.83 \\
\hline \multicolumn{6}{|c|}{ Homogeneity $=0.5833+0.0416 *$ BSF Protein } \\
\hline Thickness & $<0.0001$ & $\begin{array}{l}\text { Not } \\
\text { Significant }\end{array}$ & BSF protein & 0.75 & 0.70 \\
\hline \multicolumn{6}{|c|}{ Thickness $=0.5752+0.00391 *$ BSF Protein } \\
\hline Stress & $<0.0001$ & $\begin{array}{l}\text { Not } \\
\text { Significant }\end{array}$ & $\begin{array}{l}\text { BSF protein, Time, Temperature, } \\
\text { BSF protein-Temperature }\end{array}$ & 0.78 & 0.75 \\
\hline \multicolumn{6}{|c|}{$\begin{array}{l}\text { Stress }=10.2765-0.1658 * \text { BSF Protein }+0.2047 * \text { Time }-0.0409 * \text { Temperature }+0.0008 * \text { BSF } \\
\text { Protein } * \text { Temperature }\end{array}$} \\
\hline Strain & $<0.0001$ & Not significant & $\begin{array}{l}\text { BSF proteins, time, temperature, } \\
\text { BSF proteins-temperature, } \\
\text { BSF proteins-time }\end{array}$ & 0.98 & 0.97 \\
\hline \multicolumn{6}{|c|}{$\begin{array}{l}\text { Strain }=58.8921-1.4634 * \text { BSF Protein }-1.1459 * \text { Time }-0.3376 * \text { Temperature }+0.0700 * \text { BSF } \\
\text { Protein } * \text { Time }+0.0089 * \text { BSF Protein } * \text { Temperature }+0.0185 * \text { Time } * \text { Temperature }-0.0006 * \text { BSF } \\
\text { Protein } * \text { Time } * \text { Temperature }\end{array}$} \\
\hline E & $<0.0001$ & Not significant & $\begin{array}{l}\text { BSF proteins, temperature, } \\
\text { BSF proteins-temperature, } \\
\text { BSF proteins-time, } \\
\text { time-temperature }\end{array}$ & 0.96 & 0.94 \\
\hline \multicolumn{6}{|c|}{$\begin{array}{l}\mathrm{E}=+434.7218-1.8559 * \text { BSF Protein }-35.8875 * \text { Time }-2.5234 * \text { Temperature }+0.2762 * \text { BSF } \\
\text { Protein } * \text { Time }+0.0332 * \text { BSF Protein } * \text { Temperature }+0.2737 * \text { Time } * \text { Temperature }-0.0031 * \text { BSF } \\
\text { Protein } * \text { Time } * \text { Temperature }\end{array}$} \\
\hline
\end{tabular}

with values all above 0.70 and in some cases (Strain and $E$ ) well above 0.90 . The Pred- $\mathrm{R}^{2}$ values are all lower than the respective $\mathrm{R}^{2}$ and this fact is consistent with Pred- $\mathrm{R}^{2}$ definition [18]. The normal distribution of the residuals has been analyzed (data not reported) confirming that each model can be used to explore the region of interest, supporting investigation on more in-depth correlations of significant terms.

Graphical description of the factor influence (in single or in interaction) on the responses is shown in Figs. 2 and 3 . The contour plots are reported for each response of the investigated property, through color variations from the
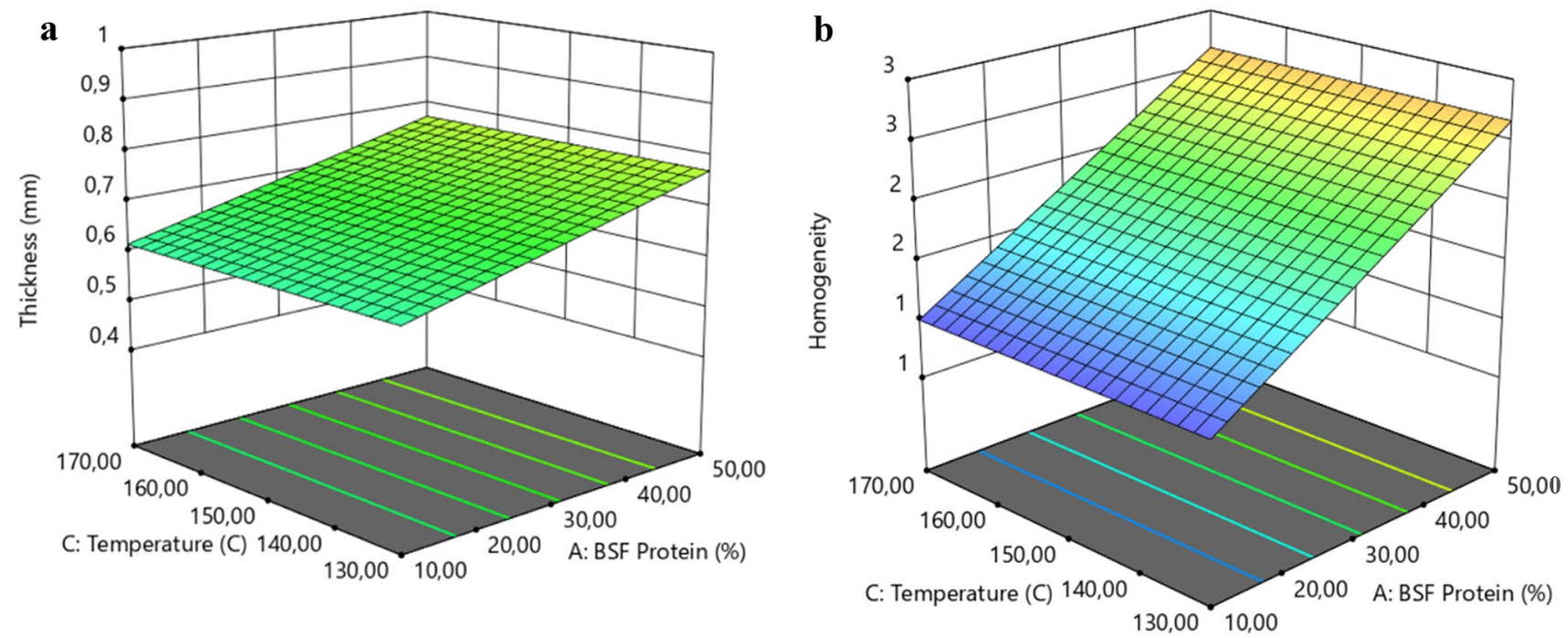

Fig. 2 Contour plots of responses: a Thickness; $\mathbf{b}$ homogeneity 

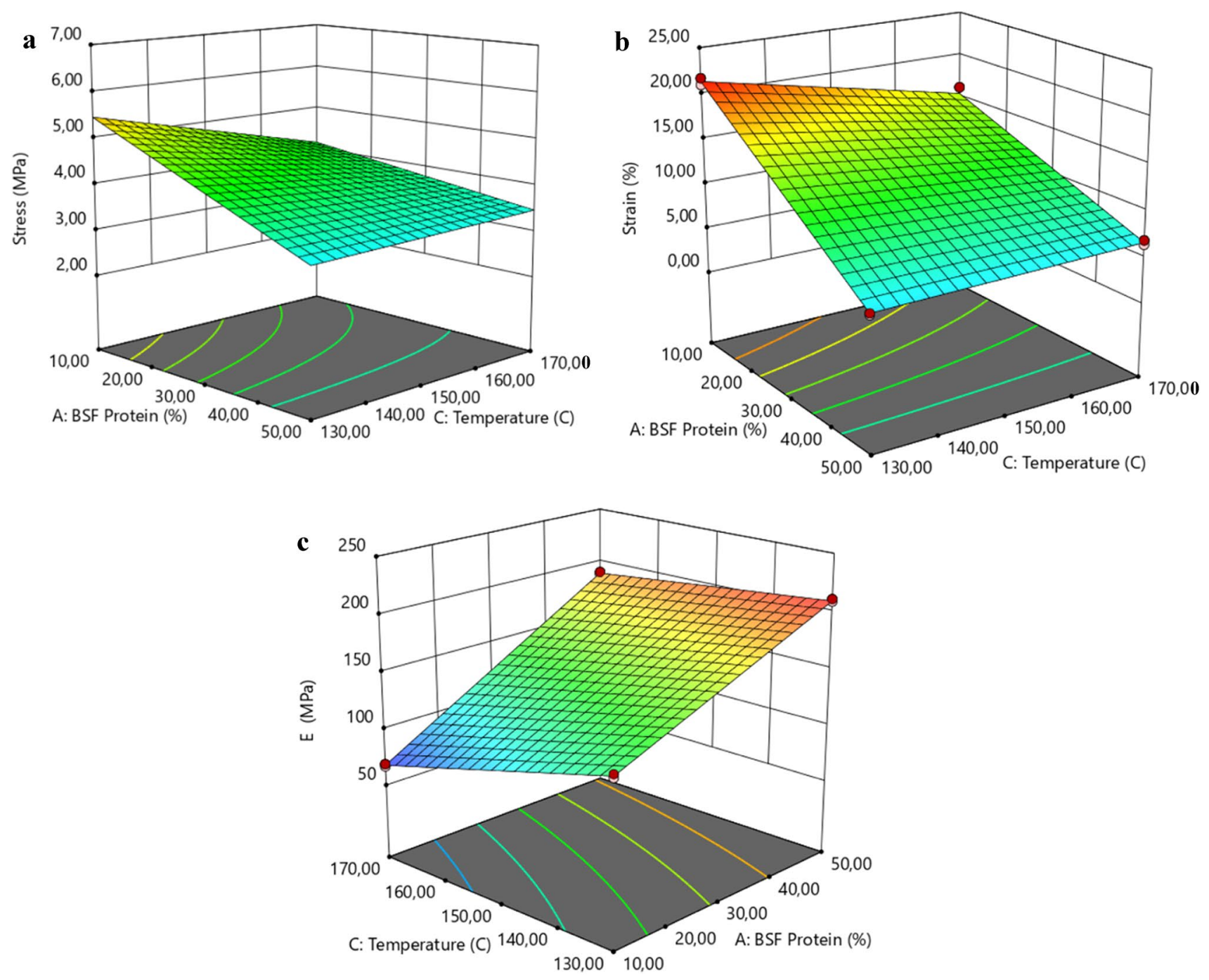

Fig. 3 Contour plots of responses: $\mathbf{a}$ stress (time $=5.5 \mathrm{~min})$; $\mathbf{b}$ strain $($ time $=5.5 \mathrm{~min}) ; \mathbf{c} \mathrm{E}($ time $=3)$

higher value (red/orange area) to lower values (green/blue area). It is possible to detect a similar behavior for Thickness (Fig. 2a) and Homogeneity (Fig. 2b) due to independent factors variation. Moreover, the effect of increasing BSF Protein has been analyzed and calculated for these responses, considering that Temperature and Time are not significant terms as reported in Table 4. A statistically significant increase in Thickness and Homogeneity can be observed with the augmenting amount of BSF Protein employed, from 10 to $50 \mathrm{wt} \%$, following a linear trend with a stronger slope for Homogeneity when compared with Thickness. Indeed, an increasing Homogeneity is observed from 1 to 3 , whereas only a moderate increase of Thickness can be detected from 0.6 to $0.8 \mathrm{~mm}$. This result suggests that increasing the amount BSF Protein into the mixture strongly favors the increase of the Homogeneity of the samples (Fig. 2b), thus leading to a more constant dispersion of BSF Protein into the LDPE volume. On the other side, only a restrained increment of Thickness can be observed (Fig. 2a). In fact, the overall range of Thickness reported is quite limited $(0.6-0.8 \mathrm{~mm})$ suggesting a possible rearrangement of the LDPE structure, considering that LDPE, as derived from PE, is composed of only carbon and hydrogen, and these two elements can be combined obtaining various molecular architectures, favoring the copolymerization with other comonomers [22].

Considering the mechanical properties (Fig. 3) a more complex behavior can be observed, as also suggested from the data reported in Table 4, where a wide range of interaction among the independent factors is significant for the mechanical properties' variation. A higher interaction concerns BSF Protein and Temperature, therefore these two independent factors have been reported graphically keeping Time as constant. A significant decrease in Stress and 


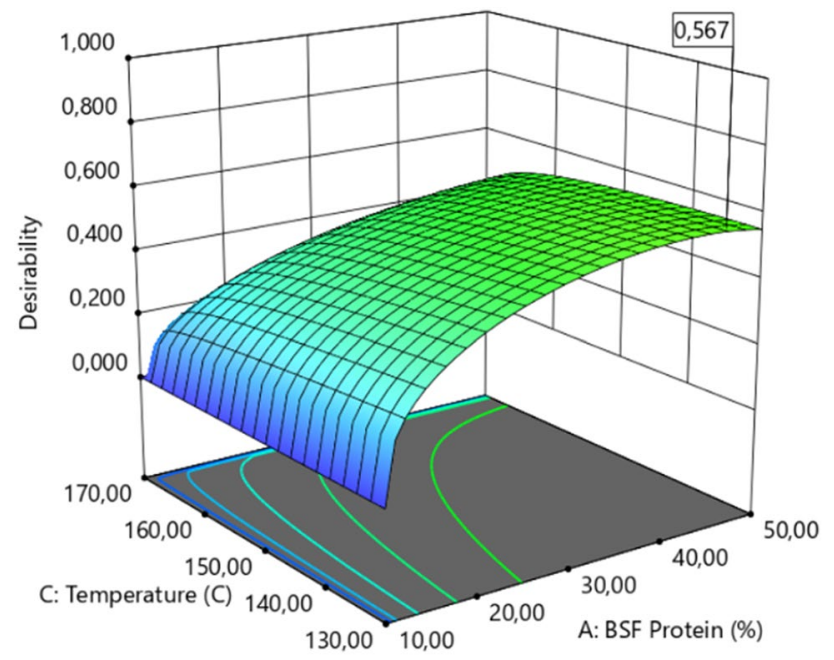

Fig. 4 Desirability function contour plots

Strain is observed by following from the lower to the higher values of BSF Protein, more precisely from 10 to $50 \mathrm{wt} \%$, emphasizing that the inclusion of $B S F$ proteins contribute to a strong modification of the LDPE network (Fig. 3a and b). Moreover, a decreasing of Stress is observed from 5 to $2 \mathrm{MPa}$ and a decreasing of Strain is observed from $20 \%$ to near $0 \%$, thus a Temperature increasing $\left(170{ }^{\circ} \mathrm{C}\right)$ has a beneficial effect reducing partially Stress and Strain fall, thanks to a better mixing of the blends. Thereafter, at high Temperature the lower Stress that can be reached is equal to 3.5 MPa and the lower Strain is equal to 6\%. On the opposite the analysis of the Young modulus- $E$ (Fig. 3c) shows a strong and linear augmentation when the highest $B S F$ Protein $(50 \%)$ amount and lowest Temperature $\left(130^{\circ} \mathrm{C}\right)$ are applied, probably because temperature is involved in into the BSF proteins degradation. Increasing the Temperature, the BSF proteins are more sensitive to a partial degradation, leading to a weaker network structure with LDPE, as also suggested from the DSC diagram of BSF proteins reported in literature [23, 24]. In addition, from Fig. $3 \mathrm{c}$ it is possible to see a strong synergic effect among $B S F$ protein and Temperature being the main condition able to reach the highest value of E equal to $200 \mathrm{MPa}$.

As shown by the desirability function (Fig. 4), the decreasing of processing Temperature $\left(130{ }^{\circ} \mathrm{C}\right)$ associated with the increasing of BSF proteins (50\%) enhances the optimization of the materials, by strongly limiting the degradation properties. On the contrary, a quantity of $B S F$ protein below $30 \%$ and a Temperature over $160{ }^{\circ} \mathrm{C}$, should be decisively avoided. Considering the above, it is worth noting that Time has a lower effect than Temperature. Nevertheless, LDPE - BSF protein best mixtures, explored in the present study, fail at relative low strain and stress ( $20 \%$ and $5 \mathrm{MPa}$ ). The overall balance among mechanical properties and sustainability makes them the more promising alternative compared to vegetable-based biopolymer, and among several animal protein-based biopolymers tested in previous studies [25, 26].

\section{Conclusion}

Proteins extracted from Black Soldier Fly (Hermetia illucens.-BSF), reared on chicken manure or food processing leftovers, are suitable to be mixed with a petroleum derived plastic, LDPE. LDPE-BSF protein blends lead to a material with a quite restrained thickness, suitable for agricultural purposes, and with potential on decreasing the negative effects on the environment as mulching film. The Design of Experiments approach allowed the investigation on the influence of BSF proteins and processing parameters on physical and mechanical properties of a new category of bioplastic, in a systematic way. Mathematical model's calculation suggest that temperature and time of processing have a restrained impact on the mechanical properties of the plastic. On the opposite, in order to avoid the loss of mechanical properties, BSF proteins content must be carefully considered. Notably a higher stress at break is not fundamental for its employment as mulching film, as it is not a structural application. Nevertheless, to achieve a trend comparable to other bioplastic materials already available on the market, improvements, such as decrease of thickness and increase tensile stresses, should be considered for future research (e.g., by including environmentally green mixture components). This rational study supports the optimized choice of agro-food waste and leftovers to derive functional products, using insects as bioconverters. In addition, this study confirms that proteins extracted from BSF are highly compatible with conventional LDPE and feasible to manufacture to obtain bioplastic, which could present promising applicability for agricultural purposes.

Author Contributions All authors contributed to the study conception and design. Material preparation, data collection and analysis were performed by all the authors. The first draft of the manuscript was written by SB and all authors commented on previous versions of the manuscript. All authors read and approved the final manuscript.

Funding This study was funded by the Emilia Romagna region in the framework of the project "ValoriBio" co-financed by 2014-2020 POR FESR. Emilia-Romagna Region. Italy. DGR 774/2015-CUP E42I15000110009 and the Rural Development Plan 2014-2020 Op. 16.1.01-GO EIP-Agri-FA 5C. Pr. "BIOECO-FLIES" and coordinated by CRPV. The authors declare that there is no conflict of interests.

\section{Compliance with Ethical Standards}

Conflict of interest The authors declare that they have no conflict of interest. 


\section{References}

1. European Union. European Commission: Communication from the Commission to the European Parliament, the Council, the European Economic and Social Committee snd the Committee of the Regions: a European strategy for plastics in a circular economy. COM(2018) 28 Final. SWD(2018), 1-18 (2018). https ://doi.org/10.1021/acs.est.7b02368

2. Brodhagen, M., Goldberger, J.R., Hayes, D.G., Inglis, D.A., Marsh, T.L., Miles, C.: Policy considerations for limiting unintended residual plastic in agricultural soils. Environ. Sci. Policy 69, 81-84 (2017). https://doi.org/10.1016/j.envsci.2016.12.014

3. Steinmetz, Z., Wollmann, C., Schaefer, M., Buchmann, C., David, J., Tröger, J., Muñoz, K., Frör, O., Schauman, G.E.: Plastic mulching in agriculture. Trading short-term agronomic benefits for longterm soil degradation? Sci. Total Environ. 550, 690-705 (2016). https://doi.org/10.1016/j.scitotenv.2016.01.153

4. Brodhagen, M., Peyron, M., Miles, C., Inglis, D.A.: Biodegradable plastic agricultural mulches and key features of microbial degradation. Appl. Microbiol. Biotechnol. 99(3), 1039 (2014)

5. Dobbin, C.: An industrial chronology of polyethylene. In: Spalding, M.A., Chatterjee, A.M. (eds.) Handbook of Industrial Polyethylene and Technology, pp. 3-24. Wiley, New York (2017)

6. Yue, H.-B., Cui, Y.-D., Shuttleworth, P.S., Clark, J.H.: Preparation and characterisation of bioplastics made from cottonseed protein. Green Chem. 14, 2009 (2012). https://doi.org/10.1039/ c2gc35509d

7. Banse, M., van Meijl, H., Tabeau, A., Woltjer, G., Hellmann, F., Verburg, P.H.: Impact of EU biofuel policies on world agricultural production and land use. Biomass Bioenergy 35, 2385-2390 (2011). https://doi.org/10.1016/j.biombioe.2010.09.001

8. Biron, M.: Industrial applications of renewable plastics: environmental, technological, and economic advances. William Andrew, Norwich (2016)

9. Emadian, S.M., Onay, T.T., Demirel, B.: Biodegradation of bioplastics in natural environments. Waste Manage. 59, 526 (2017)

10. Mazerolles, T., Heuzey, M.C., Soliman, M., Martens, H., Kleppinger, R., Huneault, M.A.: Development of co-continuous morphology in blends of thermoplastic starch and low-density polyethylene. Carbohydr. Polym. 206, 757-766 (2019). https://doi. org/10.1016/j.carbpol.2018.11.038

11. Sessini, V., Arrieta, M.P., Raquez, J.M., Dubois, P., Kenny, J.M., Peponi, L.: Thermal and composting degradation of EVA/Thermoplastic starch blends and their nanocomposites. Polym. Degrad. Stab. 159, 184-198 (2019). https://doi.org/10.1016/j.polymdegra dstab.2018.11.025

12. Barbi, S., Messori, M., Manfredini, T., Pini, M., Montorsi, M.: Rational design and characterization of bioplastics from Hermetia illucens prepupae proteins. Biopolymers (2019). https://doi. org/10.1002/bip.23250

13. Bortolini, S., Macavei, L.I., Saadoun, J.H., Foca, G., Ulrici, A., Bernini, F., Malferrari, D., Setti, L., Maistrello, L., Ronga, D., Maistrello, L.: Hermetia illucens (L.) larvae as chicken manure management tool for circular economy. J. Clean. Prod. 262, 121289 (2020). https://doi.org/10.1016/j.jclepro.2020.121289

14. Wang, H., Rehman, K.U., Liu, X., Yang, Q., Zheng, L., Li, W., Cai, M., Li, Q., Zhang, J., Yu, Z.: Insect biorefinery: a green approach for conversion of crop residues into biodiesel and protein. Biotechnol. Biofuels 10, 1-13 (2017). https://doi. org/10.1186/s13068-017-0986-7

15. Spinelli, R., Neri, P., Pini, M., Barbi, S., Montorsi, M., Ferrari, A.M.: Using black soldier flies (Hermetia illucens) to bioconvert waste from the livestock production chain: a life cycle assessment case study. WIT Trans. Ecol. Environ. 231, 47-58 (2019). https:// doi.org/10.2495/WM180051

16. Gold, M., Tomberlin, J.K., Diener, S., Zurbrügg, C., Mathys, A.: Decomposition of biowaste macronutrients, microbes, and chemicals in black soldier fly larval treatment: a review. Waste Manag. 82, 302-318 (2018). https://doi.org/10.1016/j.wasman.2018.10.022

17. Setti, L., Francia, E., Pulvirenti, A., de Leo, R., Martinelli, S., Maistrello, L., Macavei, L.I., Montorsi, M., Barbi, S.R.D.: Bioplastic film from black soldier fly prepupae proteins used as mulching: preliminary results. Agronomy 10, 933 (2020)

18. Montgomery, D.C.: Design and analysis of experiments, 8 th edn. Wiley, New York (2012)

19. Barbi, S., Macavei, L.I., Fuso, A., Luparelli, A.V., Caligiani, A., Ferrari, A.M., Maistrello, L., Montorsi, M.: Valorization of seasonal agri-food leftovers through insects. Sci. Total Environ. 709, 136209 (2020). https://doi.org/10.1016/j.scitotenv.2019.136209

20. Caligiani, A., Marseglia, A., Leni, G., Baldassarre, S., Maistrello, L., Dossena, A., Sforza, S.: Composition of black soldier fly prepupae and systematic approaches for extraction and fractionation of proteins, lipids and chitin. Food Res. Int. 105, 812-820 (2018). https://doi.org/10.1016/j.foodres.2017.12.012

21. ISO, E.: ISO 527-1 - Plastics-Determination of tensile properties-Part 1: general principles (1996)

22. Patel, R.M.: Types and basics of polyethylene. In: Spalding, M.A., Chatterjee, A.M. (eds.) Handbook of Industrial Polyethylene and Technology, pp. 105-138. Wiley, New York (2017)

23. Ganglani, M., Carr, S.H., Torkelson, J.M.: Influence of cure via netxork structure on mechanical properties of a free-radical polymerization thermoset. Polymer (Guildf) 43, 2747 (2002)

24. Barbi, S., Barbieri, F., Andreola, F., Lancellotti, I., Barbieri, L., Montorsi, M.: Preliminary study on sustainable NPK slow-release fertilizers based on byproducts and leftovers: a design-of-experiment approach. ACS Omega 5, 27154-27163 (2020). https://doi. org/10.1021/acsomega.0c03082

25. Felix, M., Romero, A., Cordobes, F., Guerrero, A.: Development of crayfish bio-based plastic materials processed by small-scale injection moulding. J. Sci. Food Agric. 95, 679-687 (2014). https ://doi.org/10.1002/jsfa.6747

26. Niaounakis, M.: Agriculture/forestry/fishery. Wiley, Fargo (2015)

Publisher's Note Springer Nature remains neutral with regard to jurisdictional claims in published maps and institutional affiliations.

\section{Authors and Affiliations}

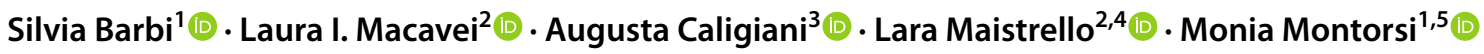

Silvia Barbi

silvia.barbi@unimore.it
Department of Science and Methods for Engineering, University of Modena and Reggio Emilia, Via Amendola 2, 42122 Reggio Emilia, Italy 
2 Department of Life Sciences, University of Modena and Reggio Emilia, Via Amendola 2, 42122 Reggio Emilia, Italy

3 Department of Food and Drug, University of Parma, Parco Area delle Scienze 27/A, 43121 Parma, Italy

4 Interdepartmental Center for Agri-Food Biological Resources Improvement and Valorization, BIOGEST-SITEIA,

University of Modena and Reggio Emilia, Piazzale Europa 1, 42124 Reggio Emilia, Italy
5 Interdepartmental Center for Industrial Research and Technology Transfer in the Field of Integrated Technologies for Sustainable Research, Efficient Energy Conversion, Energy Efficiency of Buildings, Lighting and Home Automation, EN\&TECH, University of Modena and Reggio Emilia, Piazzale Europa 1, 42124 Reggio Emilia, Italy 